\title{
POST-PANDEMIC ECONOMIC RECOVERY WITH BAITUL MAAL WAT TAMWIL
}

\author{
Erna Sofriana IMANINGSIH ${ }^{1}$, Daru ASIH ${ }^{2}$, Noermijati NOERMIJATI ${ }^{3}$, Mochmad SOELTON $^{4 *}$, \\ Rizky PRIBADI ${ }^{5}$, and Erni RAHAYU ${ }^{6}$ \\ 1,2,3,4,5 Universitas Mercu Buana \\ ${ }^{3}$ Brawijaya University \\ ${ }^{6}$ Ahmad Dahlan Institute Technology \&Business \\ *soelton@mercubuana.ac.id
}

\begin{abstract}
Baitul Mal Wat Tamwil (BMT) is a non-bank financial institution as an integrated independent business center which is a bayt al-mal wa at-tamwil, which is an institution that develops productive and investment businesses to improve the quality of small entrepreneurs' businesses and encourage business forms. -a form of investment with the aim of empowering worldly and ukhrawi businesses through donations, zakat and alms. In its development, BMTs face the same problems, for example problematic customers. Sometimes there is a customer who is not only having problems in one place, but also in other places. Therefore, each BMT needs efforts to coordinate in order to narrow down the movements of problematic customers. BMTs also tend to face other BMTs as competitors to be defeated, not as partners or partners in an effort to exclude people from the economic problems they face. So that it causes the level of competition that is not Islamic and will even affect the BMT management pattern. However, in its development, BMTs face the same problems, for example problematic customers. Sometimes there is a customer who is not only having problems in one place, but also in other places. Therefore, each BMT needs efforts to coordinate in order to narrow down the movements of problematic customers. BMTs also tend to face other BMTs as competitors to be defeated, not as partners or partners in an effort to exclude people from the economic problems they face. So that it causes the level of competition that is not Islamic and will even affect the BMT management pattern.
\end{abstract}

Keywords: BMT, Sharia Financial Institutions, Micro Finance Institutions, Social Impact

\section{BACKGROUND}

After the establishment of Bank Muamalat Indonesia (BMI), there was an opportunity to establish banks based on sharia principles. The operationalization of BMIs did not reach small and medium enterprises, so there were attempts to establish banks and microfinance institutions, such as Islamic BPRs and BMTs which aimed to overcome operational obstacles in the regions. Besides that, in the midst of people's lives who live well-off, there is a concern that the erosion of the faith will arise, this is not only influenced by the aspect of Islamic syiar but is also influenced by the weakness of the community's economy. As narrated from the Prophet sallallaahu,Alaihi Wasallam, ,poverty is close to kufr"،, the existence of BMT is expected to be able to overcome this problem by fulfilling the economic needs of the community. On the other hand, some communities have had to deal with moneylenders or loan sharks. According to Ramli et. al, (2019), Nowadays, some people in Indonesia have begun to care about the dangers of riba and its impact on the economy. Saratian et, al. (2019) said that Muslims have believed that riba is haram. Some of them certainly can define as well as interpret the term of riba.

The rise of loan sharks in the midst of society has resulted in the community being increasingly plunged into uncertain economic problems. The magnitude of the influence of loan sharks on the community's economy is due to the absence of sufficiently accommodating elements in solving problems faced by the community. Therefore, it is hoped that BMT will be able to play a more active role in improving this condition. The ups and downs of BMT development in Indonesia cannot be separated from the obstacles they face. Among the most crucial is the unclear legal basis. Because most BMTs have cooperative legal entities, they cannot legally raise funds from the community directly. BMT must require membership for the customer to be served, or make the customer a prospective member for a certain period of time. Not only do some prospective customers become reluctant, but also cause internal problems within the BMT because each member has the same voting rights, if BMT wants to be able to raise funds directly from the public, the BMT must change its legal status to a bank or non-bank financial institution, such as venture capital.

According to Sihombing (2019), The failure of the current economic and monetary system is caused by riba of fractional reserve requirement in the banking system activity. According to the perspective, Islam always encourages the practice of real assets and forbids illusionary assets. One example of a product developed at BMT is a financing product with the principle of buying and selling of goods, this product is developed in order to meet market needs that may not be included in a production sharing agreement, for example, meeting the needs of consumer goods can only be served with a contract approach. buy and sell. And one of the financing products with the principle of buying and selling for consumptive needs that is practiced at BMT is to use the bai ,al murabah contract, which is the sale and purchase of goods at the original price plus the agreed profit.

Baitul Mal wa Tamwil is a guided independent business center whose core content is bayt al-mal wa altamwil with activities to develop productive businesses and investment in improving the quality of economic activities for small and small entrepreneurs by, among other things, encouraging saving activities and supporting the financing 
of their economic activities. BMT has two fields of work, namely as a Mal Institution (Baitul Mal) and as a Tamwil institution (Baitul Tamwil). Baitul Mal is meant to collect zakat and infaq as well as alms and distribute it to entitled parties in the form of cash and capital loans without profit sharing, in which Baitul Mal is non-profit (social).

BMT develops productive businesses and investments in improving the quality of economic activities of macro and micro entrepreneurs by, among other things, encouraging saving activities and supporting the financing of their economic activities. BMT uses a cooperative legal entity and is often referred to as a sharia financial services cooperative (KJKS). The business developed by BMT is the financial sector, namely savings and loans. This business is like a banking business, namely collecting funds from members and prospective members (customers) and distributing them to the halal and profitable economic sector. BMT is oriented towards efforts to improve the welfare of members and the community so that it is hoped that BMT members (customers) can improve their standard of living through increasing their business.

One example of a product developed at BMT is a financing product with the principle of buying and selling goods, this product was developed in order to meet market needs that may not be included in a profit-sharing contract. buy and sell. And one of the financing products with the principle of buying and selling for consumptive needs that is practiced at BMT is to use a bai' al murabah contract, namely buying and selling goods at the original price plus the agreed profit.

However, in its development, BMTs face the same problems, for example problematic customers. Sometimes there is a customer who is not only having problems in one place, but also in other places. Therefore, each BMT needs efforts to coordinate in order to narrow down the movements of problematic customers. BMTs also tend to face other BMTs as competitors to be defeated, not as partners or partners in an effort to exclude people from the economic problems they face. So that it causes the level of competition that is not Islamic and will even affect the BMT management pattern. According to Saratian (2019), the family is the smallest organization but has a great impact for all its members, one of which is in the formation of a conscious and wise character in transaction and financial management. Sejati (2021), show that the main problems that arise in the development of Islamic cooperatives, one of which is Human Resources (HR) who are not yet professional. With these conditions it is deemed necessary to conduct socialization to the community to develop BMT in the future.

Basically, people without knowledge are sentient and ignorant creatures as the word of Allah Subhanahu Wa Ta'ala „Verily, we have revealed the message to the heavens, the earth and the mountains, then all are reluctant to assume that mandate and they are worried that they will betray it, and be endured. that mandate by humans. Indeed, man is very wrong and very ignorant "(Al-Qur'an, Al-Ahzab: 72). Humans have turbulent passions, always feel lacking and never feel satisfied, according to their character and characteristics. Thus, halal transactions are no longer the main goal because they are often associated with minimal profits, a long and difficult process to obtain. This is also in line with the words of the Prophet Shallallahu 'Alaihi Wasallam, from Abu Hurairah Radhiyallahu'Anhu, that he Shallallahu 'Alaihi Wasallam said ,there will come a time to mankind, they will no longer care about how to obtain wealth, whether through lawful means. or in an unlawful way ,(HR. Bukhari).

Rasulullah Shallallahu 'Alaihi Wasallam has also conveyed threats to those who eat illicit wealth. He Shallallahu 'Alaihi Wasallam said," actually will not enter the paradise of meat that grows from illicit wealth. Hell is more appropriate for him ,(HR Ahmad and Ad-Darimi). Sustenance must come from a halal source and the purpose of use must also be channeled to those who do not violate the Shari'a, as the words of the Prophet Shallallahu 'Alaihi Wasallam ,will not shift the footprints of a servant on the Day of Resurrection, until he is asked about four cases, (ie): about: his age for what he spent, about his body for what he used, about his wealth where he got it and where he put it, and about his knowledge, what he had practiced „(HR. At-Tirmidzi and Ad-Darimi). Likewise from Jabir's friend Radhiyallahu 'Anhu, that the Prophet Shallallahu "Alaihi Wasallam said: „Do not assume that your fortune is slow down. Truly, no one leaves this world, but after his income is complete. Look for fortune in a good way (by) taking the halal and leaving the haram matters ,,(HR AlHakim and Al-Baihaqi).

According to Chair (2014), riba is an addition to more than the original capital, riba transactions are usually often found in accounts receivable debt transactions where creditors ask for additional capital from the original to the debtor. Riba is often also translated to mean additional money on capital obtained in a way that is prohibited by Shara ', either with a small additional amount or even with a large additional amount. Riba (interest) has become the fad of every conventional financial transaction. This is an idea postulated by the capitalist not minding its implication to the economy in as far as they are accumulating wealth out of it (Mohammad, 2016).

According to Ghofur (2016), the Qur'an itself has explained in detail the stages of the prohibition of riba. The first stage simply describes the negative elements in riba (Al-Qur'an, Ar-Ruum, 30 : 39). Then followed by the sign of forbidden riba with the delivery of condemnation of the Jews who practice riba (Al-Qur'an, An-Nisa 4 : 160-161). Next, the Qur'an explicitly forbids riba with the limitation of adh fan mudhā afan (Al-Qur'an, Ali Imron, 3 : 130) which is followed by a total prohibition of riba in various forms (Al-Qur'an, Al-Baqarah, 2 : 275 - 276).

Allah Subhanahu Wa Ta'ala shows the prohibition of riba in the Al-Qur'an as follows: 
"And something riba (additional) that you give so that he adds to human wealth, then riba does not add to the side of God. And, what you give in the form of zakat that you mean to achieve the pleasure of Allah, then (who do so) are the people who multiply (the reward)" (Al-Qur'an, Ar-Ruum, 30: 39).

"So, because of the tyranny of the Jews, we forbid them from eating good food (which was formerly) lawful for them, and because they prevented many (people) from the path of Allah, and caused them to eat riba, when in fact they were forbidden from him, and because they ate people's wealth in a vanity. We have provided for those who disbelieve among them a painful punishment" (AlQur'an, An-Nisa 4: 160-161).

"O you who believe, do not eat riba by multiplying and fear you of Allah so that you will have good fortune. Preserve yourself from the fires of hell, provided for those who disbelieve" (Al-Qur'an, Ali Imron, 3: 130).

"People who eat riba cannot stand, but stand like people who are possessed by devils because of (pressure) insanity. That is because they say that buying and selling is the same as riba. Though Allah has justified the sale and purchase and forbid riba. Anyone who gets a warning from his Lord, then he stops, then what he has obtained first belongs to him and his affairs (it's up to) to God. Whoever repeats, they are the inhabitants of hell, they are eternal in it. Allah destroys riba and fertilizes alms. Allah does not like anyone who remains in disbelief and is wrapped in sin" (Al-Qur'an, Al-Baqarah, 2: 275 - 276).

"O you who believe, fear Allah and leave the rest of riba (that has not been collected) if you are a believer. So, if you don't work (leaving the rest of riba) then know that Allah and His Messenger will fight you. However, if you repent (of riba taking), then for you the subject of your treasure; you are not persecuting nor persecuted" (Al-Qur'an, Al-Baqarah, 2: 278 - 279).

The prohibitions and threats for usurers in some of the Hadiths are as follows:

From Abdullah bin Hanzhalah, that the Prophet Shallallahu 'Alaihi Wasallam said: "One dirham of riba money consumed by someone in a state of knowing that it is riba money is greater than adultery 36 times" (HR. Ahmad and Ath-Thabrani).

From Ibn Mas'ud, that the Prophet Shallallahu 'Alaihi Wasallam said: "Riba has 73 doors (levels), the lowest (sin) is the same as someone who commits adultery with his mother!" (HR. Al Hakim and Al Baihaqi).

From Jabir, that the Prophet Shallallahu 'Alaihi Wasallam condemned those who received riba, those who paid it, and those who recorded it, and two of their witnesses, then he said, "They are all the same" (HR. Muslim).

From Aun bin Abi Juhaifa, "My father bought a slave whose job was to burn (to get dirty blood from the body), my father then destroyed the slave's cupping equipment. I asked father why he did it. My father replied, that the Prophet Shallallahu 'Alaihi Wasallam forbade receiving money from the transactions of blood, dogs, and kasab women slaves, he also cursed the work of tattoo makers and who asked for tattooing, receiving and giving riba and he cursed the makers of drawings" (HR. Bukhari).

It was from Abdurrahman bin Abu Bakr that his father said "Rasulullah Shallallahu 'Alaihi Wasallam prohibits the sale of gold and gold and silver with silver unless it is equal in weight, and allows us to sell gold with silver and vice versa as we wish" (HR. Bukhari). "That he was blessed by two angels and they said, 'Come with us.' Until finally the two angels took him to a river of blood, in the river there was a person who was swimming. Meanwhile on the banks of the river there was one more person. When the person in the middle of the river wants to pull over, the man on the edge of the river throws his mouth with stones, until he returns to his original place (middle of the river of blood). Then the Prophet Shallallahu 'Alaihi Wasallam said: 'I asked the two angels about the person who was in the river. 'They answered,' The person you came to, who swam in the river and then his mouth was gagged with stones, he is a usurious eater" (HR. Bukhari).

\section{METHOD}

According to Ridwan (2013), Baitul Mal Wat Tamwil is a guided independent business center whose core content is bayt al-mal wa al-tamwil with activities to develop productive businesses and investment in improving the quality of economic activities of small and low-income entrepreneurs by, among others, encouraging activities save and support the financing of economic activities. BMT has two fields of work, namely as a Mall Institution (Baitul Mal) and as a Tamwil (Baitul Tamwil) institution. Baitul Mal is meant to collect zakat and infaq as well as alms and distribute to entitled parties in the form of cash or capital loans without profit sharing, in which the Baitul Mal is non-profit (social).

In this Islamic financial management learning assistance activity will be carried out by providing knowledge including the understanding of BMT, how to manage Islamic finance. The target of this online learning system is BMT members who are in the North Kembangan area. With the COVID-19 pandemic, this activity is being carried out online using a video call application. In this activity there will also be group discussions for the participants.

Through the delivery of Islamic financial management learning materials, it is hoped that the participants will be able to understand how to manage Islamic financial management. With this understanding, it is hoped that the participants can minimize the obstacles in managing Islamic finance. Activities will be evaluated through 
pre and post tests. Questionnaire for evaluating the implementation of activities related to the implementation of socialization activities.

\section{RESULT AND DISCUSSION}

The choice of workshop or training as the main activity in PPM is because it can produce benefits: (a) Through BMT learning assistance activities, it is hoped that participants can absorb the material presented properly so that the learning is carried out to be more effective and efficient. (b) after participating in this activity, it is hoped that the participants will have more knowledge and understanding so that they can apply Islamic financial management.

The purpose of this activity is to provide socialization and counseling to improve the drugs awareness in South Meruya, West Jakarta. The objectives of this activity include: (a) providing learning for BMT members in the North Kembangan area so that BMT members can manage Islamic finance, (b) increasing the role and participation of society in the BMT, (c) increasing the knowledge of society to the halal transaction practice.

\section{CONCLUSION}

Based on the discussion from the previous chapter, in this PPM training activity, the following conclusions can be drawn: (a) the participants 'knowledge in this case is that the participants' knowledge about BMT is categorized as lacking, (b) it can be concluded that there has also been an increase in the knowledge, awareness and practice of the participants.

The suggestions that can be given after going through the results of the evaluation are as follows: (a) continuous PPM training activities are needed so that assistance can run more optimally, (b) materials should be provided directly together by conducting simulations or examples using data-the data they have so that participants can better understand the material presented, (c) mentoring activities are needed for participants who can take advantage of the routine schedule of community activities.

So do not be surprised if Allah Subhanahu Wa Ta'ala threatens the perpetrators of riba with such a heavy threat and a great sin, as he said:

"O you who believe, fear Allah and leave the rest of riba (that has not been collected) if you are a believer. So, if you don't work (leaving the rest of riba) then know that Allah and His Messenger will fight you. However, if you repent (of riba taking), then for you the subject of your treasure; you do not persecute nor are you persecuted" (Al-Qur'an, Al-Baqarah, 2: 278 - 279).

Furthermore, the Prophet Muhammad Shallallahu 'Alaihi Wasallam conveyed a threat to the perpetrators of riba in the following Hadiths:

From Abdullah bin Hanzhalah, that the Prophet Shallallahu 'Alaihi Wasallam said: "One dirham of riba money consumed by someone in a state of knowing that it is riba money is greater than adultery 36 times" (HR. Ahmad and Ath-Thabrani).

From Ibn Mas'ud, that the Prophet Shallallahu 'Alaihi Wasallam said: "Riba has 73 doors (levels), the lowest (sin) is the same as someone who commits adultery with his mother!" (HR. Al Hakim and Al Baihaqi).

From Aun bin Abi Juhaifa, "My father bought a slave whose job was to burn (to get dirty blood from the body), my father then destroyed the slave's cupping equipment. I asked father why he did it. My father replied, that the Prophet Shallallahu 'Alaihi Wasallam forbade receiving money from the transactions of blood, dogs, and kasab women slaves, he also cursed the work of tattoo makers and who asked for tattooing, receiving and giving riba and he cursed the makers of drawings" (HR. Bukhari).

"That he was blessed by two angels and they said, 'Come with us.' Until finally the two angels took him to a river of blood, in the river there was a person who was swimming. Meanwhile on the banks of the river there was one more person. When the person in the middle of the river wants to pull over, the man on the edge of the river throws his mouth with stones, until he returns to his original place (middle of the river of blood). Then the Prophet Shallallahu 'Alaihi Wasallam said: 'I asked the two angels about the person who was in the river. 'They answered, 'The person you came to, who swam in the river and then his mouth was gagged with stones, he is a usurious eater" (HR. Bukhari).

\section{REFERENCES}

Azra, Azyumardi (2003). Berdema Untuk Semua. Jakarta: PT. Mizan Publika.

Djazuli A dan Yadi Yanwari (2002). Lembaga-Lembaga Perekonomi Umat Sebuah Pengenalan. Jakarta: Rajawali Press. digilib.uinsby.ac.id

Ramli, Y., Saratian, E. T. P., Soelton, M., \& Setiawan, M. (2019). RIBA PROHIBITION FOR THE COMMUNITY ECONOMIC SUSTAINABILITY. In ICCD (Vol. 2, No. 1, pp. 612-615).

Ridwan A. H. (2013). Manajemen Baitul Mal Wa Tamwil Cetakan 1. Bandung: Pustaka Setia.

Saratian, E. T. P., Arief, H., Soelton, M., Vizano, N. A., \& Mugiono, M. (2019). DINAR AND DIRHAM; SUSTAINABLE MONEY FOR SUSTAINABLE SOCIETY. In ICCD (Vol. 2, No. 1, pp. 517-521).

Saratian, E. T. P., Soelton, M., Mugiono, M., \& Muhtadin, M. (2019). KNOWLEDGE OF "MAGHRIB" (MAYSIR, GHARAR AND RIBA) FOR THE HALAL TRANSACTION OF THE COMMUNITY. In ICCD (Vol. 2, No. 1, pp. 33-37).

Sarwo, S. E., \& Rayuningsih. (2021). PERANAN BAITUL MAAL WAT TAMWIL DALAM 
MENINGKATKAN USAHA MIKRO MELALUI PEMBIAYAAN MUDHARABAH (Studi Kasus BMT Fajar Cabang Cileungsi Bogor Periode 20182019). JESPB: Jurnal Ekonomi Syariah Pelita Bangsa, 6(01), 47 - 54. https://doi.org/10.37366/ jespb.v6i01.176
Sihombing, L., Saratian, E. T. P., Soelton, M., Permana, D., \& Noermijati, N. (2019). FULL RESERVE REQUIREMENT BANKING SYSTEMFOR THE COMMUNITY ECONOMIC SUSTAINABILITY. In $I C C D$ (Vol. 2, No. 1, pp. 542-545). 